\title{
Dentistry in Brazil: Its History and Current Trends
}

\author{
Nemre Adas Saliba, D.D.S., M.Sc., Ph.D.; Suzely Adas Saliba Moimaz, D.D.S., M.Sc., \\ Ph.D.; Cléa Adas Saliba Garbin, D.D.S., M.Sc., Ph.D.; Diego Garcia Diniz, D.D.S.
}

Abstract: The objectives of this article are to provide a short history of dentistry and dental education in Brazil and to analyze the nature of its development to date. The databases consulted are those provided by the Brazilian Federal Council of Dentistry, Brazilian Ministry of Health, Brazilian Ministry of Education, National Institute of Studies and Educational Research Anísio Teixeira, and Brazilian Institute of Geography and Statistics. Formal dental education in Brazil started in the late nineteenth century with the creation of courses annexed to existing schools of medicine in Rio de Janeiro and Bahia. Today, there are 191 institutions of higher education nationwide granting degrees in dentistry (137 private [71.7 percent] and fifty-four public [28.3 percent]), with a total of 17,157 student positions offered annually. These schools graduate around 10,000 professionals per year-one of the highest rates in the world. Both the distribution of schools of dentistry and of dentists varies among the regions of the country, with the greatest concentrations in major metropolitan centers with high population density, resulting in limited coverage in the more deprived regions. A review of epidemiological data for oral health and distribution of dentists in Brazil indicates that there is a lack of systematic planning for the allocation of the dental workforce and a lack of consideration of regional needs in the development of dental training programs in Brazil today.

Dr. Saliba is Professor, Department of Child and Social Dentistry; Dr. Moimaz is Adjunct Professor, Department of Children and Social Dentistry; Dr. Garbin is Adjunct Professor, Department of Children and Social Dentistry; and Dr. Diniz is a master's degree candidate in preventive and social dentistry - all at the Dental School of Araçatuba, Paulista State University, UNESP. Direct correspondence and requests for reprints to Dr. Diego Garcia Diniz, Programa de Pós-Graduação em Odontologia Preventiva e Social, Núcleo de Pesquisa em Saúde Coletiva, NEPESCO, Rua José Bonifácio, 1193 Vila Mendonça, CEP:16015-050, Araçatuba/SP, Brazil; 18-3636-3249 or 3636-3250;18-3636-3332; diegogdiniz@hotmail.com, secrdos@foa.unesp.br.

Key words: schools of dentistry, dentist, dental education, labor market, Brazil

Submitted for publication 9/11/08; accepted 11/6/08

$\mathrm{H}$ istorically, the development of the dental profession can be divided into five stages: 1) the initial or undifferentiated occupational stage, when individuals did not dedicate themselves exclusively to the practice of dentistry and, as such, dentistry was practiced by witch doctors and magicians, among others; 2) the occupational differentiation stage, when the profession was exercised as a craft, but extensive training was not offered; 3 ) the initial professional stage, characterized by the establishment of dental schools that provided basic training, but professional development was absent; 4) the intermediate professional stage, when the profession consolidated itself as a course of study within the general framework of higher education; and 5) the advanced professional stage, when the discipline incorporated technical, biological, and social studies in order to develop expertise at the postgraduate level, thus distinguishing dentistry as a unique discipline. ${ }^{1}$
In Europe during the twelfth century, the Catholic Church outlawed surgical practices based on the belief that interventions involving the flow of blood were incompatible with sacred doctrine. With the banning of medicine in monasteries, barbers who assisted in healing procedures applied what they learned in the streets and became known as "barber surgeons." ${ }^{2}$ The practice of dentistry in Brazil exists since the sixteenth century and primarily involved dental extractions, using rudimentary instruments, with little or no consideration of hygiene. Regulation of the profession started in 1856 with the granting of titles to those who received informal training in the craft. ${ }^{3}$

The histories of dentistry and medicine in Brazil are connected, as in many other regions of the world, which makes it difficult to isolate the precise origin of dental practice in this nation. Formal dental education in Brazil started in 1879 with the introduction of the discipline called "Dental Surgery," which 
was assigned to schools of medicine. The Emperor of Brazil, Dom Pedro II, formalized dentistry by decree as a profession in 1884, and shortly after, dental-oriented courses were created in schools of medicine in Rio de Janeiro and Bahia. By 1900, dentistry was also established as a profession in Europe and in the United States. ${ }^{4}$

In 1911, the discipline called "Dental Technique" was introduced in Brazil, which involved training on mannequins for learning; this step represented an advance in the technical aspects of dental education. In 1919, dental education in Brazil developed into a four-year degree program that emphasized basic knowledge in biology and methodology. From 1933, dental schools had become autonomous, and the profession started to differentiate itself from medicine, which allowed some schools to develop specialization beyond basic training.

In the last fifty years, the influence of North American dental practices on Brazilian dentistry has been significant. Until 1971, the national core curriculum leading to the D.D.S. degree included biology, morphology, physiology, general and dental pathology, dental clinic, social and preventive dentistry, pediatric dentistry, restoration, and dentistry and professional development. ${ }^{2}$ Dentistry in Brazil is still evolving as a result of the Law of Guidelines and Bases of $1996^{5}$ and the National Curricular Guidelines of 2002, ${ }^{6}$ both of which guide educational policy in this field. An analysis of the distribution of dental schools, practicing dentists, and the labor market for this profession nationwide is important in order to develop further educational policy in this field.

The purpose of this study was to analyze the characteristics of the dental profession and dental education in Brazil, including number of dental schools and distribution of trained professionals nationwide.

\section{Methodology}

This analysis was based on consultation of secondary data available from public Brazilian agencies including the Ministry of Health, Ministry of Education, National Institute of Studies and Educational Research Anísio Teixeira, the Brazilian Institute of Geography and Statistics, and the Federal Dentistry Council.

\section{Results}

Current data show that, in Brazil, 191 training programs in dentistry are offered; of these, 137 are in private universities (71.7 percent) and fifty-four in public universities ( 28.3 percent). In the 1995 to 2008 period, 102 new dental schools were created, resulting in an increase of 114.6 percent (a growth of eighty-nine to 191 dentistry courses) in the capacity of institutions to graduate students nationwide. The participation of the private sector in the number of schools grew from 50.56 percent (forty-five) in 1995 to 71.7 percent in 2008 , representing an increase of ninety-two private dental schools (or 204 percent). In 1995, there were approximately 7,454 available positions in the first year of dental school throughout Brazil (4,473 in the private sector) (Figure 1). Between 1995 and 2008, there was an increase that led to 17,157 available positions for students nationwide, representing a growth of 130 percent. The private sector alone increased its share by approximately 303.1 percent, thereby increasing its available positions to 13,506 . (See Figure 2 for change in percentages of first-year positions between private and public schools.) Data from the Brazilian Ministry of Education showed that there was a growth of graduations throughout the country on the order of 38 percent. In $1995,6,964$ students graduated, followed by 9,605 in 2008. ${ }^{7}$

Brazil has an estimated population of $189,841,456$ and is the fifth largest country in territorial extension worldwide, with $8,547,403 \mathrm{~km}^{2}$. It is divided administratively and politically into twentyseven federative units, comprising twenty-six states and one federal district. The five geographic regions of the country - north, northeast, center-west, southeast, and south - are characterized by considerable social, economic, cultural, and demographic differences. Dental schools are distributed throughout the geographic regions of Brazil as follows. The southeast region has 49.7 percent (ninety-five) of the 191 Brazilian dental schools, followed by the south and northeast regions, each with 16.2 percent (thirty-one) of the schools. The north has 10.5 percent (twenty) and the center-west region has 7.4 percent (fourteen) of all dental schools (Figure 3).

Of the total 17,157 dental school positions for students in the country, 55 percent $(9,448)$ are offered in the southeast; 13.3 percent $(2,285)$ in the northeast; 13 percent $(2,243)$ in the south; 11.2 percent $(1,921)$ 


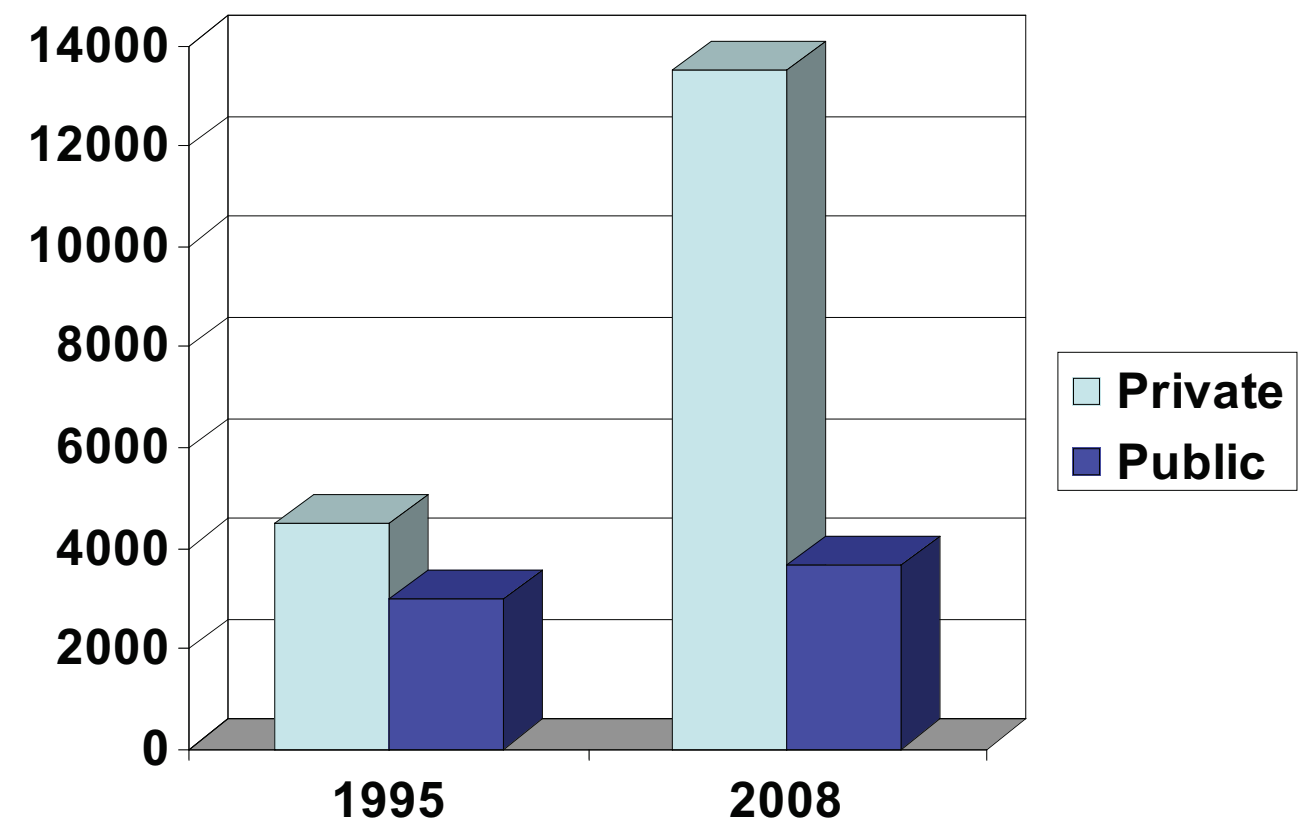

Figure 1. Number of first-year positions for students in private and public dental schools in Brazil, 1995 and 2008

1995

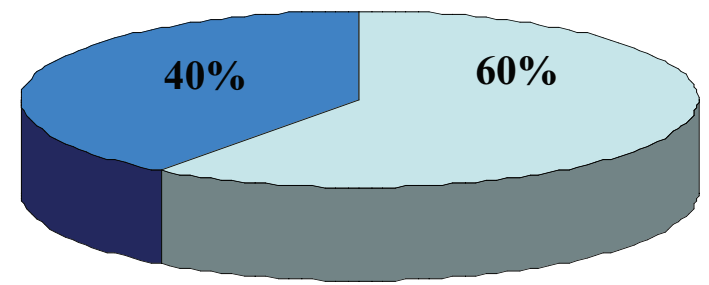

$\square$ Private $\square$ Public
2008

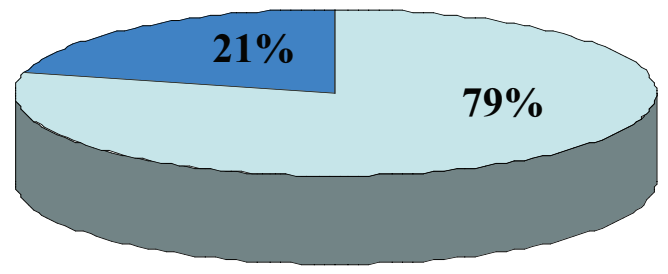

$\square$ Private $\square$ Public

Figure 2. Percentages of available positions in the first year in private and public dental schools in Brazil, 1995 and 2008 


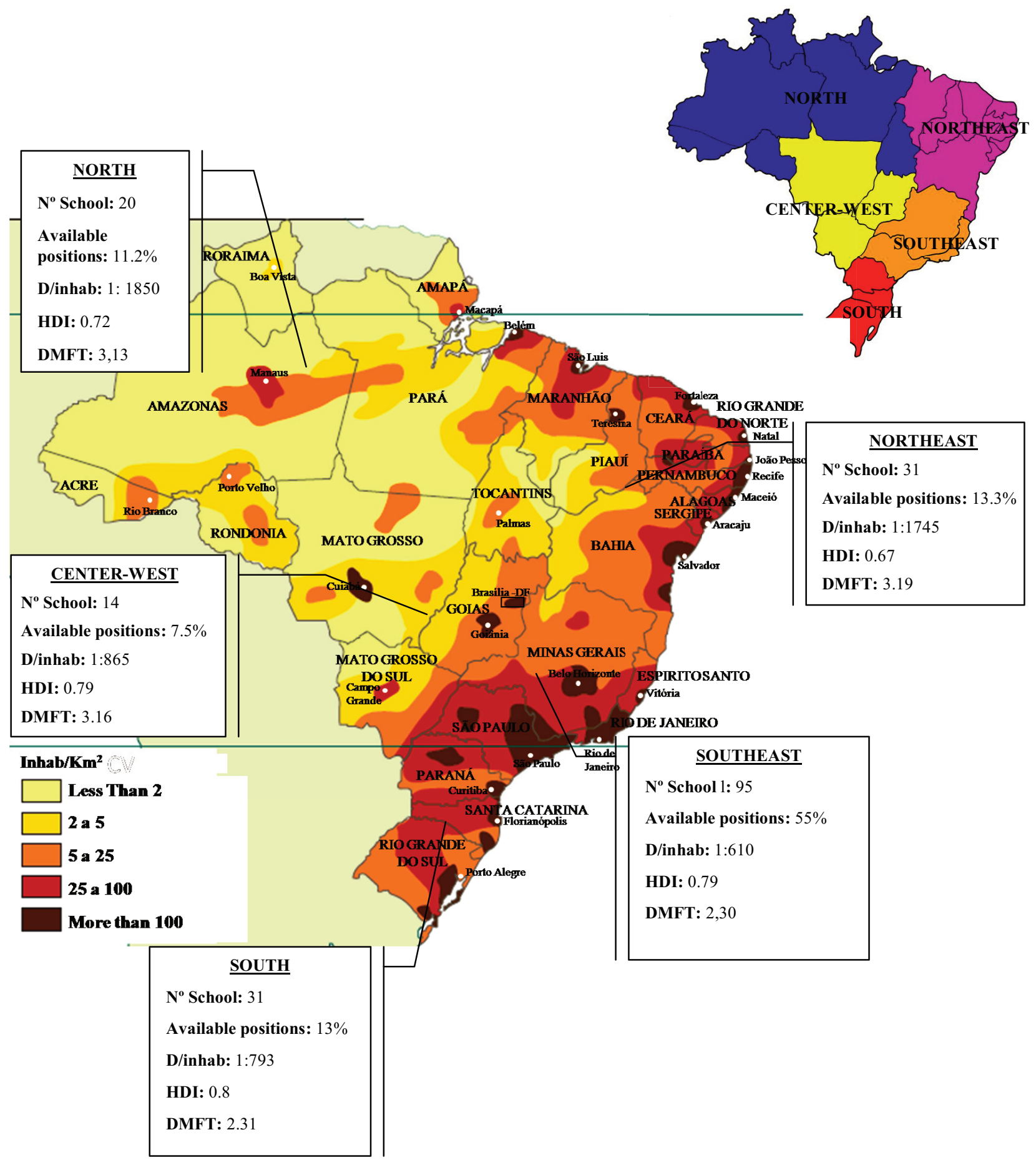

Figure 3. Distribution across Brazilian regions of dental schools, available positions, dentists per capita, HDI, and DMFT at twelve years, 2008 
in the north; and 7.5 percent in the center-west $(1,260)$ (Figure 3). As far as the number of students who have graduated is concerned, 58 percent are located in the southeastern region; 18.5 percent in the southern region; 14.3 percent in the northeastern region; 6 percent in the central western region; and 3.2 percent in the northern region. ${ }^{8}$ Currently, there are 217,340 dental surgeons in the country distributed as follows (dentist/inhabitant $=\mathrm{D} /$ inhab): north $1: 1,850$ $\mathrm{D} /$ inhab, northeast 1:1,745 D/inhab, southeast 1:610 D/inhab, center-west 1:735 D/inhab, and south 1:793 D/inhab. ${ }^{6-8}$

The largest and most comprehensive nationwide epidemiological survey on oral health ever developed in Brazil (SB Brazil) was completed in 2003. It was carried out in all the regions of the nation. It provided information on more than 100,000 oral examinations and mapped the oral health of Brazilians. Its results demonstrated that the DMFT (mean number of decayed, missing, or filled teeth) of twelve-year-olds was 3.13, 3.19, 2.30, 2.31, and 3.16 for the north, northeast, southeast, south, and center-west regions, respectively. ${ }^{9}$ These regions had the following human development indices (HDI) in 2003 for the north, northeast, southeast, south, and center-west regions respectively: $0.72,0.67,0.79$, 0.8 , and $0.79^{10}$ (Figure 3).

\section{Discussion}

Dentistry is the area of health that has expanded the most in recent years in Brazil. Quantitatively, it is the third most important health profession (the first is medicine, the second is nursing), currently with 57,000 jobs nationwide. ${ }^{11}$ Notably, in the last ten years, there has been a major expansion of the number of dental schools and of the number of people who have joined the dental profession. An important concern, nevertheless, of both professionals and the population at large is the training quality and the potential shrinking of jobs for dentists in coming years due to overproduction of dentists and resulting in market saturation. ${ }^{12,13}$

Brazil exceeds the United States and all of Europe in the number of dental schools and students, being second only to India. ${ }^{14}$ In the United States, there are fifty-six schools of dentistry, distributed in thirty-four states, with approximately 17,800 total students and approximately 4,500 new graduates each year. ${ }^{15}$ Across Europe, there are 177 academic dental institutions, and approximately 6,500 students graduate every year. ${ }^{16}$ In Brazil, currently with more than 17,000 available positions in the first year in its 191 institutions, approximately 10,000 students graduate annually. 7,8

In the 1990s, there was a rapid expansion of higher education in dentistry, mainly of private institutions. Today, 88 percent of the dental schools in Brazil are private institutions, with an enrollment of 70 percent of total students. However, until 2004, 40 percent of the positions available in private colleges were not filled. ${ }^{17}$

The distribution of dental schools in Brazil is characterized by geographical inequalities. The expansion of programs in the southeastern and southern regions, which represent the most developed areas of the country and together account for 73.1 percent of the nation's economic output, was largely related to the economic development and the purchasing power of these regions and not a direct result of actual oral health care needs of the public or dental education needs. ${ }^{18}$ As a consequence of this pattern of establishing dental schools in the regions of the nation with the highest per capita income, the distribution of dentists, based on household income and other economic indicators, varies greatly by region. The north and northeast have the lowest percentages of dentists in relation to the population and are the most adversely affected by lack of available professionals. The best ratios of dentists to population occur in the most economically developed regions of Brazil: southeast, center-west, and south.

The ratio of dentists to population is a parameter often cited in international comparisons of the availability of health care services and providers. The World Health Organization (WHO) provides no ideal or desirable statistic, since the distribution of professionals is strongly influenced by local factors such as socioeconomic levels of the population, as well as cultural and epidemiological characteristics. ${ }^{19}$ For example, in Iran, there are approximately 13,000 dentists nationwide. With a population of 71 million people, there is only one dentist for every 5,500 people and a DMFT at twelve years of 1.5. ${ }^{20}$ In Canada, with 32 million inhabitants, there are 18,287 dentists, or approximately one dentist for every 1,800 inhabitants. ${ }^{21}$ In Europe, the ratio is $1: 1,561$ inhabitants, with the following distribution for several nations in Europe: Germany 1:1,322; Italy 1:1,919; Portugal 1:2,362; Spain 1:2,495; and United Kingdom 1:2,331.22 
The number of Brazilian dentists is comparable to 12 percent of all professionals in the world. In 1998 , the ratio was $1: 1,241$, whereas today the ratio is $1: 874$. The distribution of dentists in Brazil is uneven, with averages of $1: 3,666 \mathrm{D} /$ inhab in the northern region and 1:800 D/inhab in the southeastern region. ${ }^{23}$ It is evident that Brazil has one of the largest concentrations of dentists per capita in the world. But the distribution of these professionals indicates a difference between the more and less developed regions of the nation, resulting in a lack of dental assistance for much of the Brazilian population. Other countries show similar distributions. In 1998, Hong Kong had a population of 6.6 million inhabitants and 1,542 registered dentists for a ratio of 1:4,300. But the distribution was reported to be uneven, as many dentists were concentrated in commercial districts that had a 1:2,500 dentist to inhabitant ratio, whereas in other areas of Hong Kong the ratio was 1:20,000. ${ }^{24}$ In Mexico, the status of dental practice is similar. There is no objective determination of the ratio of patients to dentists, as the practice of dentistry in Mexico is primarily urban. ${ }^{25}$ This unbalanced distribution indicates a service that targets a small portion of the population, with the majority of professionals located in the larger metropolitan areas.

While the Brazilian population is increasing by 1.89 percent per year, the growth of the dentists is approximately 7 percent annually. A similar situation exists in China, where the number of dentists is increasing by 4 percent annually, while the population is growing by only 0.9 percent. ${ }^{26}$ In the United States, the situation is reversed, as the population has grown more rapidly than the growth in the number of new dentists joining the profession. The expansion of the U.S. population at a faster rate than the expansion of dental practitioners complicates the fact that there is inadequate access to dentists for people of low socioeconomic status. ${ }^{27}$

Currently, dental schools could provide a solution to the problem of uneven distribution by addressing professional training with respect to the most relevant problems of society, including the epidemiological characteristics of regional populations. ${ }^{28,29}$ The Brazilian teaching model in practice nowadays was established by the Law of Guidelines and Bases of 1996 and the Guidelines for National Curriculum of February 2002, ${ }^{5,6}$ which have the primary goal of preparing future professionals technically, scientifically, ethically, socially, and intellectually for the dental profession. The profile of the Brazilian professional is characterized by "generalist training and a humanist and reflexive perspective based on technical and scientific rigor, with the aim of providing service at all levels of health care." 5

The pursuit of the oral health of a nation should be guided by ethical principles, and should consider the social, cultural, and economic conditions of the population, in order to transform dental practice that would benefit society. ${ }^{5}$ The general and specific skills that the dentist should acquire during training are set in the 2002 Guidelines for National Curriculum. General skills of a dentist should include ability in appropriate decision making; leadership; administrative and management skills; the ability to collect, observe, and interpret data for diagnosis, including logical reasoning and critical analysis; ability to develop appropriate treatment plans and to communicate with patients and others on the importance of oral health; knowledge of ethical and legal requirements of the profession; and the ability to work with interdisciplinary health teams and to incorporate technological innovations (information technology, new materials, biotechnology, etc.) in professional practice. ${ }^{6}$

\section{Conclusion}

Our review of dentistry and dental education in Brazil leads us to the following conclusions:

- Brazil has 191 institutions granting degrees in dentistry (137 private [71.7 percent] and fifty-four public [28.3 percent]), has 17,157 available student positions, and graduates 10,000 professionals annually.

- Despite Brazil being a nation with one of the greatest number of dental schools and practicing dentists in the world, we believe that this situation does not appear to have improved the oral health of the majority of the population.

- The greatest concentration of educational institutions and university vacancies is in the southeast region of Brazil, followed by the south, northeast, and north and center west. The worst ratios of D/ inhab and value of DMFT are in regions with the lowest number of schools and dentists, resulting in a lack of oral health care services/providers in the most needed regions. As a consequence, it is necessary to plan workforce development and the better allocation of human resources and dental services nationwide. 


\section{REFERENCES}

1. Chaves MM. Odontologia social. 3rd ed. São Paulo: Artes Médicas, 1986.

2. Andrade M. História da odontologia III: enfim, o reconhecimento. Rev ABO Nac 1999;7(1):12-7.

3. Neto AJF. A evolução dos cursos de odontologia no Brasil. Rev ABENO 2002;2(1):55-6.

4. Almeida ECS, Vendúscolo DMS, Júnior WM. A conformação da odontologia enquanto profissão: uma revisão bibliográfica. RBO 2002;59(6):370-3.

5. Brazil. Law $n^{\circ} 9394$ [establishes the guidelines and bases of the national education]. Diário Oficial da União, 1996. At: www.planalto.gov.br/ccivil_03/LEIS/19394.htm. Accessed: January 13, 2008.

6. The guidelines for national curriculum of dental education. Brazilian Ministry of Education, National Council of Education, Diário Oficial da União, 2002. At: http://portal. mec.gov.br/cne/index.php?option $=$ content\&task $=$ view\&i $\mathrm{d}=392$ \&Itemid=440. Accessed: January 13, 2008.

7. Cadastre of Brazilian universities das instituições de ensino superior. INEP/MEC (Ministry of Education). At: www.educacaosuperior.inep.gov.br/. Accessed: January 15,2008

8. Number of professionals, 2008. Brazilian Federal Council of Dentistry. CAD System Registration. At: www.cfo.org. br. Accessed: January 15, 2008.

9. Project SB Brazil. Condition of the Brazilian population: oral health. Ministry of Health. Brasília: Ministério da Saúde: 2002. At. www.cfo.org.br/download/pdf/brasil_ sorridente/resumo_sb\%20brasil.pdf. Accessed: January 20, 2008

10. Atlas of human development in Brazil. Brasilia: United Nations Development Programme (UNDP), 2003. At: www.pnud.org.br/atlas/. Accessed: January 15, 2008.

11. Project Oral Health. Condition of the Brazilian population. Oral health 2002-2003: principal results. Brazilian Ministry of Health. Work document, 2004.

12. Ferreira RA. O "milagre" da multiplicação dos cursos. Rev Assoc Paul Cir Dent 1997;51(4):310-8.

13. Botazzo C. Saúde bucal e cidadania: transitando entre teoria e a prática. In: Pereira AC. Odontologia em saúde coletiva, planejando ações e promovendo saúde. Porto Alegre: Artmed, 2003:17-27.

14. Shah N. Need for gerodontology education in India. Gerodontol 2005;22:104-5.

15. Center for Public Policy and Advocacy. Dental education at-a-glance. Washington, DC: American Dental Education Association, 2004.
16. Kravitz SA, Treasure ET. EU manual of dental practice, 2004. Cardiff: The Liaison Committee of the Dental Associations of the European Union, 2004. At: www.eudental. eu/library/104/ fi les/eu_manual_05004-20051104-1148. pdf. Accessed: February 20, 2008.

17. Brazilian Association of Dental Education (ABENO) $40^{\mathrm{a}}$ Reunião da Associação Brasileira de Ensino Odontológico. At: www.abeno.org.br. Accessed: November 23, 2007.

18. Cai a participação do Sudeste no PIB e sobe a dos estados ligados à agroindústria Brazilian Institute of Geography and Statistics (IBGE). At: wwwl.ibge.gov. br/home/presidencia/noticias/noticia_visualiza.php?id_ noticia $=470 \& i d \_p a g i n a=1$. Accessed: January 15, 2008.

19. World Health Organization (WHO). Achieving the right balance: the role of policy-making processes in managing human resources for health problems WHO/EIP/ OSD/00.2. Evidence and Information for Policy. Geneva: World Health Organization, Department of Organization of Health Services Delivery, 2000.

20. Hamid SRP. Oral health in Iran. Int Dent J 2004;54:36772.

21. Canadian Dental Association, Resource Centre \& Information Services. August 2006. At: http://cdaadc.ca/_files/ dental_profession/students/practice/pdp17_cda_resource centre.pdf. Accessed: November 18, 2007.

22. Scott J. Dental education in Europe: the challenges of variety. J Dent Educ 2000;67(1):69-78.

23. Pinto VG. Saúde bucal: odontologia social e preventiva. São Paulo: Santos, 1989:415.

24. Lo ECM, Wong MC. Geographic distribution of private dentists in Hong Kong in 1989 and 1998. Br Dent J 1999; $186: 172-3$

25. Maupomé G, Díez-de Bonilla J. La disyuntiva en la formación de recursos humanos en odontología en México. Educ Med Salud 1995;29(2):153-63.

26. Schwarz E, Lo EC, Cai LH. Dental work force in China. J Dent Res 2001;80(11):1962.

27. Ryan J. Improving oral health: promise and prospects. National Health Policy Forum Background Paper. Washington, DC: The George Washington University, 2003.

28. Feuerwerker LCM. Educação dos profissionais de saúde hoje: problemas, desafios, perspectivas e as propostas do Ministério da Saúde. Abeno 2003;3(1):24-7.

29. Eaton KA, Widstoem EA, Renson CE. Changes in the numbers of dentists and dental caries levels in 12-yearolds in the countries of the European Union and economic area. J R Soc Health 1998;118:40-8. 